\title{
ФЕНОМЕН РЕЈУВЕНАЦИЈЕ ЈЕЗИЧКИХ ЈЕДИНИЦА - КАКО СЕ ВИДИ У ПРИМЕРИМА ПРОЗНОГ ТЕКСТА МИЛОША ЦРЬАНСКОГ*
}

\footnotetext{
Аутор испитује савремене теоријске дефиниције језичке рејувенације тако што, као пишчев избор језичких јединица за рејувенацију, анализира лексичке архаизме, историјске појмове и морфосинтаксичке облике и конструкције изабране у романима Сеобе и Друга књига Сеоба М. Црњанског.

Кључне речи: рејувенација, језик прозе, Милош Црњански, архаизам, дијалектизам, језички слојеви, српски језик.
}

1. Процеси рејувенације језичких јединица свих нивоа одавно су у лингвистичкој литератури дефинисани, и - наравно - приказивани на конкретном језичком материјалу. При томе, теоријске поставке су деривиране и из говорног, и из писаног дискурса. Тако, још одавно, средином прошлог века, каже Ст. Улман (St.Ullmann): "It sometimes happens that a word which had fallen into disuse is revived and readmitted into literary language or even into ordinary speech. A number of obsolete terms, Shakesperian, Spenserian and others, were rejuvenated in this way by English writers during the Pre-Romantic and Romantic periods. The history of the word glee may serve as a warning that what may be an archaism in the usage of one generation may cease to be archaic to the next..."1. А сигурно је да треба указати и на, принципски,

\footnotetext{
* Текст је преуређена, за предавање адаптирана, ауторова расправа под насловом Pejyвенација језичких јединица у прозном тексту, објављена у Зборнику радова 35 . Научног састанка слависта у Вукове дане, 35/1, Београд, 2006, стр. 5-13. Постојећој у расправи литератури додата је и она која обрађује и више црта језика М. Црњанског.

${ }^{1}$ St.Ullmann, Language and Style, Oxford, 1966, p. 171.
} 
исти став нашег лингвисте А. Белића о језичком стваралаштву појединаца. У својој књизи Око намег књижевног језика Белић пише, de facto, исто о језику Гетеа, Пушкина, Шекспира, Толстоја, Његоша, Караџића, Мицкијевича, Словацког².

У овоме предавању покушаћу да дате теоријске поставке проверим на сегментима прозног дела Милоша Црњанског, природно - због захтева које поставља време (и простор) излагања на једном часу предавања - узетим сасвим селективно.

2. Као и сегменти прозног дела, тако су узете у разматрање, сасвим селективно и по принципу узорка, и језичке јединице које су обележене као узусно рехабилитоване, враћене у оптицај - као категорија „дијахронијског у синхронијском", како се то у теоријском делу лингвистичких истраживања констатује. Јер, наиме, „старе речи могу се поново оживети - историјски роман захвата у прошлост и враћа не само архаичне термине, него, ради сликања атмосфере, и обрте архаичне граматике"з.

Овде ће појам процеса рејувенације бити и нешто проширен, па ће се као језичке јединице које учествују у њему узимати и дијалектизми, онда када се могу тумачити као условни историзми, одн. архаизми.

3. Језик Милоша Црњанског ${ }^{4}$ сигурно је у оној категорији језичког исказа који је наука о српском језику већ окарактерисала као „богату ризницу најсавршенијег средства за међусобно општење и комуникацију"5. Као и језик сваког књижевног дела, наравно, и језик прозе М. Црњанског има и оне особине које проистичу из природе уметничке поруке, пре свега из њене сталности и непроменљивости ${ }^{6}$ с једне стране, и из деิла кому-

${ }^{2}$ А. Белић, Око намег киижевног језика, СКЗ, Београд, 1951, стр. 19-21, 31, 45, 285.

${ }^{3}$ Dwight Bolinger, Aspects of Language, New York, 1975, 385, где се даље још и уопштава о односу синхроније и дијахроније речима: "Yet the two [synchronic and diachronic approaches to language - напомена референта] cannot really be pulled apart... With old speakers and young speakers coexisting and communicating, both the past and the future are with us in the present".

${ }^{4}$ Милош Црњански, уз Иву Андрића - највећи српски писац XX века, рођен је 1893. године у Чонграду, у Мађарској. Школовао се у Панчеву и Темишвару (Румунија), универзитетске студије је започео у Бечу, а завршио их, после I светског рата у Београду. Писао је лирику и прозу. Говорио је више језика; живећи један број година у Лондону, похађао више курсева (из драматургије, филмске режије и др.). Радио је у дипломатској служби Краљевине Југославије (од 1928. године), вршећи разне дужности у југословенским амбасадама у Берлину и Риму. Време II светског рата провео је у Лондону, где од 1945. г. живи у емиграцији (од 1951. г. као британски држављанин), да би се 1965. године вратио у Београд, у којем је и преминуо 1977. године.

${ }^{5}$ М. Стевановић, Однос граматичара према норми књижевног језика, Споменица, Посебна издања САНУ, CCCLXXVII, 26, Београд, 1964, 197.

6"Le message littéraire est caractérisé par le fait qu'on ne peut y rien changer, qu'il n'admet aucune substitution dès le moment où sa composition est achevée... la discontinuité chronologique n'altère pas le message" (M. Riffatere, Vers la définition linguistique du style, Word, Volume 17, Number 3, New York, December, 1961, 329). 
никативног процеса који се у науци о језику назива перцепција поруке с друге стране. Као такав, тај језик за нашу филологију је материја која, и у целини и у појединости, улази у испитивања која је још Александар Белић задао и то одређујући им као једино логичан лингвистички став - потребу да буду грађа за историју савременог књижевног језика на тај начин што ће се у њеном грађењу ићи „од писца до писца, од књижевне врсте до књижевне врсте"».

Уз овако опште одређење језика М. Црњанског, природно, у реализацији његовог истраживања нужно се поставило и питање о томе шта из његовог језика треба да буде предмет истраживања. Ја сам се, полазећи управо од већ давно утврђеног квалитета књижевне поруке М. Црњанског написане прозом, одлучио за истраживање на принципу случајног узорка у материји сигурно најистакнутијег пишчевог прозног текста - у језику романа Сеобе, као и његовог, хронолошки узето, наставка - романа Друга књига Сеоба.

Такође, поставило се и питање: које издање те прозе анализирати да би се могло закључивати о језичким феноменима у њему као о феноменима који су изворно пишчеви? Као одговор на ова питања, наметала се, с пуно основа, идеја да се ради текстолошким методама, наравно у првој, припремној фази истраживања.

Зато сам за материју на којој ћу радити узео већ готове резултате текстолошког рада изврсног зналца и текстолошких метода, и књижевног дела М. Црњанског - Д. Иванића, који је приредио издање романа Сеобе и Друге књиге Сеоба из 1996. године. То је и било природно, јер би свака нова примена тих метода значила неекономично и непотребно понављање већ урађених послова. Језик овог издања романа Сеобе, одн. Друга књига Сеоба, дакле, узима се као изворни језик прозе М. Црњанског.

4. С обзиром на обухватност тога језика, одлучио сам се за анализу изабраних појединачних језичких појава онако како се оне издвајају као у понечем специфичне у односу на општи језички стандард, и то применом принципа случајног узорка. Те језичке појаве припадају лекси чком, морфолошком (и морфофонолошком), творбеном и синтаксичком нивоу језика.

Овде се анализирају у целовитим језичким ентитетима и због тога - нису издвојене у параграфе са називима језичких нивоа. У једном датом поглављу, на пример, налазе се и морфолошке, и творбене, и синтаксичке, као год и лексичке категорије. У неким од параграфа, опет, приказује се

${ }^{7}$ "L'ensemble du message participe du style, mais ce sont les effets qui lui donnent sa structure... la stylistique est donc la partie de la linguistique qui étudie la perception du message" (M. Riffaterre, Isto, 340).

${ }^{8}$ А. Белић, О књижевним језицима, Јужнословенски филолог, XIX, 1-4, Београд, 1951-1952, 7. 
само једна од јединица наведених језичких нивоа. Али и са тога аспекта, иако малога обима, резултати истраживања језички су потпуни и могу носити атрибуте припадања целом језичком изразу Милоша Црњанског, једног од само, можда, два - када узмемо име Иве Андрића у та два имена - највећа српска писца и језичка ствараоца не само прве половине XX века, него и целог тог столећа.

5. Унутарлингвистички аспект систематског проучавања, дакако, основан је на проучавању језичког детаља ове прозе Милоша Црњанског - романа Сеобе и романа Друга књига Сеоба. Наравно, у контексту језичке епохе у којој је писац стварао ова дела, и у контексту синхронијског језичког ос ећања у ономе смислу како је тај појам дефинисао Александар Белићํ. Управо због овог последњег, природно је и што овај општи поглед на једну посебну, рекао бих - и високо индивидуализовану - језичку материју формирам помоћу лингвистичког инструментарија који је нашој лингвистици дао и А. Белић, али и настављачи његовог метода, пре свега проф. М. Стевановић у домену конкретних изучавања српског књижевног језика, па тиме и језика најзначајнијих српских писаца. Природно, у истом контексту, у формирању мога општег погледа заступљен је и инструментариј и многих других, домаћих (П. Ивић, И. Грицкат и др.), и страних лингвиста (А. Вајан, Р. Јакобсон, Ст. Улман, В. В. Виноградов и др.).

6. И управо проучавање језичког детаља, могу рећи, упућује нас на то да су последње деценије XIX и почетак XX века, до Првог светског рата, несумњив период „брзог и углавном неометаног развоја српског књижевног језика" 10 , оног који је формирао касније солидне основе за стварање такозване школе „београдског стила”, стила који је А. Белић изједначавао са „београдским књижевним језиком”, и који се, управо по Белићевој оцени, развијао у смислу најбољих традиција Вуковог језика, уједначујући се и постајући комуникативно средство књижевних и културних кругова, чувајући углавном свој лик и примајући црте које су се из народног језика у њега уносиле на бази поменутих традиција ${ }^{11}$.

Те основе неометано остају у језичком изразу и каснијих српских писаца, међу њима и најзначајнијих као што су били - Иво Андрић и Милош Црњански, писци чији је ауторски језик ${ }^{12}$, рекли бисмо, згуснути

${ }^{9} \mathrm{~A}$. Белић, О значају језичког осећања за вршење синхроничке језичке анализе (24 X 1952), О различитим питањима савременог језика, Изабрана дела, том 13, Београд, 2000, стр. 524, 525-526, 527.

${ }^{10}$ П. Ивић, Целокупна дела, III, Преглед историје српског језика, Сремски Карловци - Нови Сад, 1998, стр. 256 и д.

${ }^{11}$ В.: А. Белић, ,, Београдски стил”, Наш језик, II, св. 7, Београд, 1934, стр. 193-200.

${ }_{12}$ За језик Ива Андрића в.: Ž. Stanojčić, Jezik i stil Iva Andrića, Filološki fakultet Univerziteta, Monografije, Knjiga XI, Beograd, 1967, str. 330. 
микрокозам врло обухватног српског књижевојезичког дијасистема. Тај систем, као што је јасно, у прозној реализацији није ништа друго до мозаик слојева општег српског језика, које писац прозног дела, зависно од своје језичке компетенције, има на располагању. И Иво Андрић, и Милош Црњански писци су који се одликују врло високим степеном те компетенције. Наравно, сваки са својом специфичношћу, али и са заједничким квалитетом - ерудицијом истинских интелектуалца XX века, ерудицијом која има свога директног одраза у заступљености језичких слојева, дијахроних и синхроних, у њиховом делу, од којега је предмет ових лингвистичких истраживања - језик прозе Милоша Црњанског, конкретно језик његових двају романа, Сеобе и Друга књига Сеоба.

7. Језичка слојевитост, логично узето, и јесте медиј рејувенације ова два романа и показује се и на нивоима морфологије и грађења речи, и на морфосинтаксичком нивоу каква је конгруенција, и на нивоу контакта међу језицима у формирању облика позајмљеница из других језика, као и на нивоу синтаксичко-семантичком, када се укрштају значења лексема везана за различите периоде у историји језика. У томе смислу поучна је (а) дистрибуција морфолошко-творбених јединица багрем - багремови - багрење; (б) слагање атрибута са именицом ухода; (в) појава основе nyдp- уместо nудер- у позајмљеници пудер и (г) синтаксичко (синтагматско) разрешавање значења именица град и варош у језику прозе М. Црњанског.

Посебно је ова слојевитост језика реализована у распореду орнаменталних језичких структура које је Црњански-наратор очигледно црпао на два извора - фолклорном (око језгра „Великомученик Цар Лазар”) и квалификованом (око језгра „блато, војник, новац”), супротстављајући их да би описао ментални склоп друштвене групације која не уме да одвоји симболе од реалија (нпр. у гл. VI и VII, са низом лексичких историзама типа: полк, граф, флоринт, великомученик одн. историјски условљених појмова, кад је реч о семантичкој страни језичке јединице, кави су: Славонско-подунавски полк, Цаберн, Цар Лазар, Мајни, Карло Лотариншки).

8. Дефинисана цильна слојевитост сигурно је остварена у пишчевој употреби форме плурала именице отаи каква је у примеру: Из којих им прочиташе и имена юихових оцева, жена, деце, форме која је типична за слој црквеног српског језика (према форми очеви, коју налазимо у општем језику), међутим, није апсолутна у сложеној језичкој материји ове прозе М. Црњанског. Наиме, У језику „Сеоба” налазимо примере:

Из којих им прочиташе... и имена њихових оцева, жена, деце (22). - Заиграше му на глави... и стотину малих Влашчића, Немчића, Маџарчића, чијим је оцевима дерао кожу с леђа (37). 
Као множину именице от ац сва релевантна литература која има елементе нормативности, па и Речник МC, наводи само ону која је основана на облику очеви. Облике изведене од оцеви обележава као покрајинске, дакле као дијалектизме (Речник МС 1971). Наравно, уколико та лексема није из црквеног језика, са значењем „православни празник посвећен оцу", како је дефинише Речник МС, дакле, уколико није - архаизам. У томе случају наводи се и у облику са $\boldsymbol{\mu}$, и у облику са $\boldsymbol{\varkappa}$ оцеви и очеви. У већим граматикама се констатује и облик без проширења -ев- : оци, с тим што се тада наводи „с посебним значењем - духовних отаца” (Стевановић 1994: 202), што је такође у сфери архаизама. За разлику од тумачења које би се свело на констатацију да је реч о дијалектизмима, овде је опет реч о сложенијем процесу у језичком осећању М. Црњанског. Наиме, у контексту многих слојева језика које је Црњански увео у језик овога романа ${ }^{13}$, претпостављам да писац облик оцеви није морао осећати као дијалектизам, па чак ни као архаизам у дословном значењу тога термина. Са тога аспекта - осећања за облик као такав (дакле - без онога што као лексема значи), облик оцеви за писца могао је бити један од облика у низу:

- књижевнојезички слој: отаи - очеви

- $\quad$ архаични слој црквеног језика: отац - оци - Очеви // Оцеви

- потпомогнут, природно, постојањем тога облика и у дијалекту, који са лексичког гледишта има вредност књижевнојезичког очеви. Пишчево „грубље огрешење о језички стандард”, дакле, могло би имати основе у изузетној активности његовог језичког ос ећања. Његово језичко осећање могло би се дефинисати као својеврстан катализаторски филтер кроз који пролази језички материјал узет из различитих слојева језика, па и оних архаичних, наравно, на индивидуалном нивоу, за разлику од колективног нивоа, о којем, као о константи свих језика, говори, на познати нам начин, и Белићева лингвистика (Белић 1958: 301). Тиме кажем да је кроз језичко осећање Милоша Црњанског пролазила вишеслојна језичка грађа, те да је он ту грађу прерађивао онако како колективно језичко осећање једног језичког поколења, Белићевом терминологијом речено, прерађује оно што у језику ствара појединац. То није ништа друго до прощес рејувенащије.

\footnotetext{
${ }^{13} \mathrm{O}$ томе, осим грађе коју уочавамо у језику романа, говоре и приређивачи кад наводе да се Црњански „огласио као читалац мемоарских записа Симеона Пишчевића”, да су код њега „запажени и трагови читања одређених дјела Доситејевог доба (стихови Милована Видаковића): језик тих дјела искоришћен је некад дословно, као непосредна, управна ријеч јунака Сеоба”, да је М. Црњански проучавао мемоаре и архивску грађу итд. (Д. Иванић, Поговор Сеобама, 1996, 367).
} 
9. Могло би се рећи да су анализиране морфолошке специфичности, дијалектизми и архаизми, које су резултат рада пишчеве језичке свести, у комплексу идиолекта М. Црњанског - јединице које представљају „стилску чињеницу", али и чињеницу обнављања употребе, враћања из историјске фазе. Дакле, да су то чиниоци рејувенације, са својом лингвистичком структуром, која има значајан утицај на књижевно дело, а њиме, као целином, и утицај на развој једног књижевног језика као историјске категорије. Процеси који претходе тој чињеници налазе се, природно, и у психолингвистичкој сфери због које, по многим испитивачима, треба узети да „неке стилске специфичности нужно одговарају извесним дубоко смештеним цртама ауторове (језичке - прим. Ж. Ст.) свести" (Ullmann, 1966, 121-126). Отуда се може рећи да је предмет овога испитивања, због природе лингвистичког испитивања, и - рад пишчеве језичке свести, једнако као и опис објективног стања језика и, уз то, анализа језичког материјала који је писац, као језички стваралац, одабрао у инвентару многих језичких слојева, па и оних архаичних, којима је суверено располагао.

10. Језичка циљност - са рејувенационим резултатом, коју је дефинисала Прашка лингвистичка школа и посебно Р. Јакобсон - врло је јасна када је искристалисана контекстуалним комбиновањем исказа у којима синтаксички микроконтекст заправо одређује различиту семантичку вредност синонимских парова, у иначе синхроном пресеку савременог језика.

Ова категорија може се утврдити у пишчевом избору језичких јединица на нивоу лексеме (варош : град), на нивоу синтагме (из града: $c a$ града), на нивоу творбе речи (сливати : изливати : лити), на нивоу језичког контакта у свим областима (честьејши, дочекан слугама, поверовати га), у којем се види више елемената примарних језичких слојева, којима М. Црњански влада.

Јер, и раније сам доказивао, надам се, и доказао циљну функцију пишчевог избора тумачећи да је пишчев циљ да означи разлику између лексеме варош "urbs" и лексеме град "castellum" / "urbs" резултирао неупотребом ове друге (град) у генитивској синтагми са предлогом $c a$. Другим речима, да је написао *звук звона дуго се сливао, са града, на њих - језичко осећање пишчеве генерације сигурно би значење лексеме протумачило као значење “castellum”. Наравно, Црњански је могао употребити и лексему град у генитивској синтагми, могао је написати: *звук звона дуго се сливао, из града, на њих - и употребити предлог из да би сачувао град са значењем “urbs". Међутим, при томе читалац не би имао информацију (или бар конотативно подсећање) и о чињеници, видљивој из непосредно претходног контекста - о звуку звона који допире $u$ Зечуја, „вароши” која се налази „н а првим брдима на која су се успели из равнице”. Дакле - информацију о идеји „висине”, која је - иначе - и имплицирана 
у лексичком значењу предлога $c a$ и јасна већ и на првом перцепцијском нивоу, како сам у датој анализи установио.

11. На основи језичке циљности, па и циљности рејувенационог карактера, формирају се многе црте идиолекатског карактера у општем књижевном језику, које, наравно, не можемо дословно схватати и дефинисати у речницима уз ознаке које их ограничавају у том општем језику. Међу такве језичке феномене понекад свакако иде и књижевниково индивидуално осећање за неки од архаичних облика. Многе црте из пишчевог идиолекта узимају се у општи српски књижевни језик, одн. у његову нормативну литературу. С тим, природно, што неке од њих, оне као што је партиципска употреба глаголског прилога садашњег у реченици из Сеоба: Дотрча, сав задуван, Исакович, те седоше у кола, обојица осрамоћени и бесни, опкољени поворком јашућих официра (Сеобе, 1996, 25) - никако нису преузете у књижевни језик.

Такви су феномени на нивоу пишчевог избора глаголских облика у исказима:

У колима, са раскошним арњевима, од ливеног гвожђа, Гарсули је изгледао, неко време, као миш у мишоловци и чинило се да му оде глава. Међутим,... гомила је само викала за њима, али их је пропустила (Друга књиге Сеоба М. Црњански, Београд, 1996, 27)

Терцини то никако није умео да објасни, иако је испитиван целог дана, иако су судије викале на њега, да је фелон и мизерија, и да му оде глава (исто, 79)

- у којима налазимо облике аориста као апсолутне стилске паралелизме са типичним архаизмима онога типа који као такве наводи граматичка литература ${ }^{14}$ :

Ако пустих жива огња, / Гњездо ћу ти попалити. - Ви идите двору бијеломе, a ja одох Смедереву граду. - Гони, Мићане, поплаћасмо главама. ${ }^{15}$

То је сасвим у духу карактеристике коју лингвисти дају за писце из периода доста раније „кристализације” српског књижевног језика - „они се нису клонили ни дијалектизама у гласовним и морфолошким појединостима. Тако се догодило да су они писали народним језиком, а да се то ипак не осети као удаљавање од књижевног"16. С тим, наравно, што се за М. Црњанског мора рећи да је тај поступак вишеструко комплекснији. О томе сведочи, на пример, његова употреба аориста, а не неког другог претериталног времена - у контексту синдетске реченице И чинило се да му оде глава, блиска примарном изразу који се налази у фолклорном

\footnotetext{
${ }^{14}$ М. Стевановић, Савремени српскохрватски језик, II. Синтакса, Београд, 19865 , стр. 651.

${ }^{15}$ Ibidem., 650-651.

${ }^{16}$ П. Ивић, Целокупна дела, VIII, Преглед историје српског језика, Сремски Карловци - Нови Сад, 1998, стр. 260.
} 
слоју језика, а који је на основи модерног српског језика - несумњиво у категорији архаизма.

Облик аориста у њему употребљен је у зависној реченици објекатског типа, која је допуна непотпуном глаголу чинити се из претходне реченице. И то - употребљен у нараторовом говору, док се наратор поклапа са самим писцем. Из овога проистиче да и сам језички исказ припада језику писца, те да је и употребљени облик аориста у њему, заправо, у рангу уобичајеног, општекомуникативног за стандардни српски језик. Тиме се несумњиво сврстава у средство рејувенације архаичног облика.

Ову чињеницу треба истаћи посебно зато што се у језику најбољих писаца XX века, оних чији је језик модерна реализација књижевног језика, онда када се модални аорист нађе у њиховој прози, дати облик с таквом функцијом обично налази у оним деловима исказа који припадају дискурсу ликова у делу. А такав аорист јесте специфичан, како сам га својевремено дефинисао, анализирајући његове примере у језику другог од двојице највећих српских писаца поменутог раздобља - Иве Андрића ${ }^{17}$. За разлику од примера из Андрићеве приповедачке прозе које сам у својој анализи навео, као што су примери:

Нит утјера рачваст колац у земљу, ни твога фра Марка у свети ред. - Помагај господин престојник, слатки! Убише ме, кукавца! - Слушај, момче, криво је мени откако знам за себе, него мјери со или ја одох код другога. - Јово, сине, побише нас!

- који, како сам рекао, сви представљају директни говор ликова, штавише - дијалекатски обојен, наведени пример из Црњанскога „Друге књиге Сеоба" припада језику самога писца и језику средине за коју пише. Као такав, неким својим елементима издваја се из категорије језичких средстава која су стилски маркирана у ономе смислу у којем су маркирани примери таквог (модалног) аориста нађени у језику Иве Андрића.

Најзад, о поступку рејувенације сведоче и друге модерне текстуре језичкоg израза прозе М. Црњанскога, који се тиме уклапа у низ других језичких стваралаца ове савремене епохе развоја општег, дакле и комуникативног српског њижевног језика XX века кроз језички израз књижевноуметниких дела.

\section{ГРАЂА}

Милош Црњански, Сеобе, Том трећи, Књига 8 и Друга књига Сеоба, Дела Милоша Црњанског, Том четврти, Књига 9, Београд, 1996.

${ }^{17}$ Ž. Stanojčić, Jezik i stil Iva Andrića, Filološki fakultet, Monografije, XI, Beograd, 1967, str. 218. 
Речник српскохрватскога књижевног језика, 2, МС и МХ, Нови Сад - Загреб, 1967; 5, Нови Сад, 1973.

\section{ЛИТЕРАТУРА}

А. Белић, „Београдски стил”, Наш језик, II, св. 7, Београд, 1934, стр. 193-200.

А. Белић, $O$ књижевним језищима, Јужнословенски филолог, XIX, 1-4, Београд, 1951-1952, 7-16.

А. Белић, Око нашег књижевног језика, СКЗ, Београд, 1951.

А. Белић, О значају језичког осећања за вршење синхроничке језичке анализе (24 X 1952), О различитим питањима савременог језика Изабрана дела, том 13, Београд, 2000.

Dwight Bolinger, Aspects of Language, New York, 1975.

Д. Иванић, Поговор Сеобама, 1996, 715-723.

Ž. Stanojčić, Jezik i stil Iva Andrića, Filološki fakultet, Monografije, XI, Beograd, 1967.

Ж. Станојчић, Из језика прозе Милоша Црњанског - лингвистичка истраживања. - Библиотека аз, књига 5, Завод за уџбенике, Београд, 2008.

M. Riffatere, Vers la définition linguistique du style, Word, Volume 17, Number 3, New York, December, 1961, 315-329.

М. Стевановић, Однос граматичара према норми књижевног језика, Споменица, Посебна издања САНУ, CCCLXXVII, 26, Београд, 1964, 197-209.

М. Стевановић, Савремени српскохрватски језик, II. Синтакса, Београд, $1986^{5}$.

П. Ивић, Целокупна дела, VIII, Сремски Карловци - Нови Сад, 1998.

St. Ullmann, Language and Style, Oxford, 1966. 